\title{
Supervening impossibility of the provision of sports training and coaching due to the 'coronavirus'
}

\author{
Alejandro Valiño ${ }^{a}$ \\ a University of Valencia, Valencia, Spain.
}

\section{ABSTRACT}

The paper analyses the situation of the contracts to provide services that persons or sport organisations agree with their students in the context of expanded health crisis worldwide caused by the coronavirus. Given the diverse background of the readers, reference to specific national or local regulations will be avoided. Instead, general principles of the service contract contained in some studies that have dealt with the transnational harmonisation of private law are considered.
Key words: Covid-19, Provision of services, Supervening impossibility, DCF, European Contract Code. Received: 25 April 2020

Accepted: 30 June 2020 Corresponding author: Alejandro Valiño, Department of Roman Law and State Canon Law, University of Valencia, Valencia, Spain. Email: alejandro.valino@uv.es

\section{INTRODUCTION}

The provision of tennis coaching and training services is included in one of the most traditional contracts in any national legal system ${ }^{1}$. The most common names are 'service leasing' ${ }^{2}$, ' service location ${ }^{3}$ or 'provision of services' ${ }^{4}$, defined as

\begin{abstract}
"contract under which one party, the service provider, undert akes to supply a service to the other party, the client, in exchange for a price" ${ }^{\prime \prime}$.
\end{abstract}

As per the people that take part we can distinguish, on the one hand, the offeror or supplier of the service, who, depending on the situation may be a self-employed coach or a sports club, which has astaff which delivers the organisation, management and execution of sports training and coaching programmes in their facilities. It is even possible that, in a certain sports organisation, both options coexist in harmony: one, organised by the entity, consisting of group training lessons for players of all ages and playing levels by coaches related to it through the so-called 'work contract', characterised by its dependency and foreignness ${ }^{6}$; and another, in which a group of coaches, related or not to the organisation as members, provides their free services to the users of the facility, usually in the format of individual lessons.

In addition to the provider of the service, we cannot forget the user, recipient of the service or simply client, who is the player or student that participates in any coaching or training

\footnotetext{
${ }^{5}$ Art. IV.C - 1:101 (a) of the DCFR. Vid. DE BARRÓN ARNICHES, P. (2008), 12 ss. and BELUCHE RINCÓN, I. (2015), 76.

${ }^{6}$ CRESPO, C., VALIÑO, A., CRESPO, M. (2016), 37.
} 
programme and pays a fee or sum of money (negotiated between the parties or included in an offer directed to the public), either in advance, either at the end of each session, or even later after a period of time or number of sessions ${ }^{7}$.

The peculiarity of this contract lies in the fact that, even though it arises from the time the parties reach an agreement (or the client shows his willingness to adhere to the offer), the collection of the rent is closely linked to the effective provision of the service under the conditions agreed. Therefore, when the person compelled to provide the service fails to do so (i.e. does not provide the service) or does it poorly (it does not fulfil the conditions agreed or offered, for example, the type of court in which the practice should have been delivered; or unilaterally substitutes the agreed coach, when this appointment was decisive to contract the service) ${ }^{8}$, the client, who always can terminate a contract of this type ${ }^{9}$, may also claim compensation for the damages suffered ${ }^{10}$.

\section{$\begin{array}{llll}\text { EFFECTS ON } & \text { THE } & \text { CONTRACT } & \text { OF }\end{array}$ THE TEMPORARY IMPOSSIBILITY OF THE PROVISION}

However, there are extraordinary situations, beyond the will and control of the service provider, that determine the unexpected impossibility of complying, definitively or temporarily, with what has been agreed ${ }^{11}$. One of them is precisely the Covid-19 pandemic. Its rapid spread has forced many States to impose confinement on their citizens on their homes and the indefinite closure of all kinds of establishments, including sports facilities.

In this way, the coaching and training programmes have been temporarily suspended (except for those physical activities that could have been continued using e-learning modes), which has triggered not a little uncertainty, given the time of interruption of the service. The situations have also been heterogeneous, since the forms of payment for these services are certainly variable: there are cases in which the service for an entire season is paid in advance, with the result that the temporary impossibility of continuing to receive the coaching has caused an economic imbalance to the customer.

In any case, the unexpected impossibility of the provision may cause different effects on the contract, depending, above all, on its duration. The coaching and training services are successive, since the programme is usually divided into a number of sessions during several days a week over several months within the same or successive seasons. For this reason, the principle of conservation of the contracts makes it difficult to terminate them in situations of temporal impossibility of the provision when the service was agreed for a long time, so that calamities like the pandemic of the Covid19 just cause the suspension of the delivery of the services agreed in the contract, which will resume only when the government measures that make impossible their compliance on time will be risen. As soon as the conditions for the practice of sport have been re-established, the parties will proceed to comply with what is incumbent upon them, recomposing, by means of negotiation, the provision imbalance eventually produced. Thus, if the student had prepaid the service for an entire season, the imbalance could be corrected by reimbursing the price corresponding to that part of the service not provided or, alternatively, by issuing bonds or other formulas of equivalent value that they suppose for the client a reasonable compensation, so that he himself or the person designated by him could receive classes or training outside the hours or periods of ordinary provision of the service.

\footnotetext{
${ }^{11}$ Art. 97.2 del CEC, versión original: " si après la conclusion du contrat la prestation devient objectivement impossible, pour des raisons dont le débiteur ne doit répondre, il n'y a pas inexécution de l'obligation (...". Art. III. - 3:703 del DCFR: "the debtor in an obligation which arises from a contract (...) is liable only for loss which the debtor foresaw or could reasonably be expected to have foreseen at the time when the obligation was incurred as a likely result of the nonperformance, unless the non-performance was intentional, reckless or grossly negligent".
} 
A fundamental element in bilateral contracts such as services is that of contractual good faith ${ }^{12}$. In accordance with it and in view of the supervening impossibility of the provision due to causes beyond the control of the contracting parties, it is essential that the parties show an interest to reach a benefit rebalancing agreement, so that fierce positions, be on the part of the provider, determined to bear on the recipient of the service all the consequences derived from the impossibility of its provision, either by the client, obstinate in rejecting the formulas that the offeror may propose, would openly violate that requirement of good faith in the contract.

\section{CONCLUSION}

The unsuccessful impossibility of providing sports coaching and training services implies, in principle, a mere suspension in the provision of the services agreed, as it is a successive contract, so that, as soon as the government measures that made sports impossible were disappeared, the parties must renegotiate the contract with the purpose of restoring the provision balance in those cases in which, according to what has been agreed, such situation has occurred.

\section{REFERENCES}

ACCADEMIA DEI GIUSPRIVATISTI EUROPEI(2014). C odice european dei contratti. Secondo Book, Titolo Secondo, arts. 230-298, 'Dei contratti di servizi ', Milano.

DE BARRÓN ARNICHES, P. (2008). Questions about the service contract designed in the Common Reference Framework. InDret. Magazine for the analysis of Law 3, pp. 1-29.

BELUCHE RINCÓN, I. (2015), The service contract: the client's right to withdraw unilaterally. REVIEW of Civil Law II.2, pp. 69-126.

CRESPO, C., VALIÑO, A., CRESPO, M. (2016). EI tennis coach and Law: Case Studies (III). E-Coach. Electronic Magazine of the Tennis Technician, 26, pp. 35-42.

VON BAR, C. ET A LII (2009). Principles, Definitions and Model Rules of European Private Law. Draft Common Frame of Reference (DCFR). Outline Edition, Munich, Sellier European Law Publishers, 2009, pp. 302-310, https://doi.org/10.1515/9783866537279
RECOMMENDED ITF TENNIS ACADEMY CONTENT (CLICK BELOW)

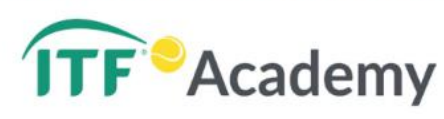

Copyright (c) 2020 Alejandro Valiño

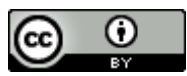

This text is under a Creative Commons BY 4.0 license

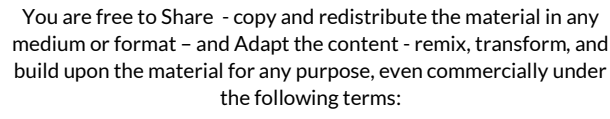

Attribution: You must give appropriate credit, provide a link to the license, and indicate if changes were made. You may do so in any reasonable manner, but not in any way that suggests the licensor endorses you or your use.

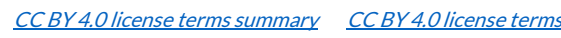

12 Art. 241.1 del CEC: "le parti (...) hanno il dovere di comportarsi secondo buona fede, senza alcuna reticenza e con spirito di reciproca e leale cooperazione, al fine di consentire il raggiungimento di tutti i risultati che ciascuna parte intende conseguire (...)". El art. I.- 1:103 (1) del DCFR la define como "standard of conduct characterised by honesty, openess and consideration for the interests of the other party to the transaction or relationship in question". 